\title{
Pengaruh Kesadaran, Kualitas Pelayanan, Dan Pemeriksaan Pada Kepatuhan Wajib Pajak Bermotor Di Kabupaten Gianyar
}

\author{
Ni Putu Krismayanti ${ }^{1}$ \\ Ni Ketut Lely Aryani Merkusiwati ${ }^{2}$ \\ ${ }^{1,2}$ Fakultas Ekonomi dan Bisnis Universitas Udayana (Unud), Bali,Indonesia \\ e-mail: yantikrisma6@gmail.com
}

\begin{abstract}
ABSTRAK
Penelitian ditujukan demi hasil bukti yang empiris dari pengaruh kesadaran wajib pajak, kualitas pelayanan pajak dan pemeriksaan pajak pada kepatuhan wajib pajak kendaraan bermotor di Kabupaten Gianyar. Kabupaten Gianyar merupakan tempat penelitian. Seluruh wajib pajak kendaraan bermotor yang tersebar di Kabupaten Gianyar merupakan populasi penelitian ini. Metode pengambilan sample accidental sampling digunakan untuk mengambil sampel yang sebanyak 100 orang wajib pajak. Kuisioner digunakan sebagai alat pengumpulan data dengan teknik analisi datanya adalah regresi linier berganda hasil anasisis data menunjukan bahwa kesadaran wajib pajak, kualitas pelayanan pajak dan pemeriksaan pajak berpengaruh positif signifikan pada kepatuhan wajib pajak kendaraan bermotor di Kabupaten Gianyar.
\end{abstract}

Kata kunci : Kepatuhan, kesadaran, kualitas pelayanan, pemeriksaan .

\begin{abstract}
The purpose of this research was to obtain empirical evidence from the influence of taxpayer awareness, tax service quality and tax audit on motor vehicle taxpayer compliance in Gianyar Regency. This research was conducted in Gianyar Regency. The population in this study were all Motor Vehicle taxpayers scattered in Gianyar Regency. The number of samples in this study were 100 respondents using the sampling method was accidental sampling. Data collection is done using a questionnaire. The data analysis technique used is multiple linear regression analysis. Based on the results of data analysis, it can be seen that, taxpayer awareness, tax service quality and tax audit have a significant positive effect on motor vehicle taxpayer compliance in Gianyar Regency.
\end{abstract}

Keywords: Compliance, awareness, service quality, examination.

\section{PENDAHULUAN}

Kebijaksanaan tentang adanya otonomi daerah atau desentralisasi membuat setiap daerah bertanggung jawab atas pengelolaan daerah. desentralisasi fiskal serta kerangka otonomi daerah menyumbangkan pernyataan transparan untuk wilayah dalam melakukan pelayanan, pengelolaan dari pemerintah dengan pedoman partisipatif, transparatif, dan akuntabel. Pengelolaan wilayah termasuk dalam pengelolaan keuanganannya (Prastiwi \& Satyawan, 2014). Pengelolaan keungan 
dietiap daerah juga termasuk dalam segi perpajakannya (Arum \& Sukartha, 2017). Desentralisasi juga merupakan instrumen untuk mencapai tujuan negara. Pencapaian dari tujuan negara akan membuat kerangka persatuan nasional yang demokratis (Kaluge et al, 2015).Pajak adalah aspek yang fundamental dalam kehidupan yang modern. Penerimaan dari pajak membiayai pelayanan publik dan fasilitas public (Young et a., 2016). Pembayaran pajak oleh wajib pajak adalah bentuk suatu tanggung jawab serta sumbangsih secara langsung dalam melaksanakan tanggung jawab perpajakan. Kewajiban dari wajib pajak tersebut akan digunakan untuk pembiayaan negara dan pembangunan nasional (Cintya \& Lely, 2013), yang dimana pembangunan nasional hendak diselenggarakan oleh pemerintah dan masyarakatnya (Adi, 2014). Pajak bukanlah hanya sebatas itu, melainkan merupakan mekanisme yang menentukan tingkat sosial, solidaritas dan partisipasi sosial Negara (Mohdali et al, 2017). Peran perpajakan lebih dari sekedar mempromosikan pertumbuhan ekonomi. Perpajakan membentuk lingkungan di mana perdagangan dan investasi terjadi (Akinboade, 2015).

Menurut Peraturan Bupati Gianyar No. 141 Tahun 2015 tentang Tata Cara Pemungutan Pajak Kendaraan Bermotor, Pajak Hiburan, Pajak Penerangan Jalan, Pajak Air dan Tanah dan Pajak Mineral Bukan Logam dan Batuan, Penyetoran Pajak Kendaraan Bermotor di Kabupaten Gianyar sudah menerapkan official assesment system. Official assesment system dari administrasi perpajakan telah mendapatkan penerimaan yang luas dan secara global (Saad, 2014). Sistem penyetoran pajak dengan official assesment system membuat para wajib pajak membayar sendiri pajak yang terutang, sedangkan untuk perhitungan besar pajak 
yang harus dibayar, dihitung oleh petugas pajak. Dengan penerapan official assesment system diharapkan pembayaran pajak disadari oleh wajib pajak sehingga tidak ada tunggakan pajak maupun denda. Berikut ini disajikan realisasi penerimaan pajak beserta jumlah tunggakan dan denda.

Tabel 1.

Realisasi Penerimaan Pajak Kendaraan Bermotor, Tunggakan dan Denda di Kantor UPT SAMSAT Gianyar Tahun 2013-2017

\begin{tabular}{clcc}
\hline Tahun & Realisasi Penerimaan (Rp) & Tunggakan (Rp) & Denda (Rp) \\
\hline 2013 & 64.225 .380 .600 & 2.195 .871 .800 & 2.044 .021 .600 \\
2014 & 71.874 .142 .200 & 3.412 .149 .400 & 3.270 .626 .100 \\
2015 & 70.284 .820 .050 & 3.294 .242 .000 & 3.768 .924 .200 \\
2016 & 73.223 .884 .000 & 5.480 .605 .147 & 3.343 .382 .057 \\
2017 & 103.222 .010 .775 & 3.927 .672 .525 & 4.192 .325 .312 \\
\hline
\end{tabular}

Berdasarkan Tabel 1 diatas masih terdapat utang dalam bentuk tunggakan dan sanksi dalam bentuk denda wajib pajak pada UPT Kantor Bersama SAMSAT Gianyar. Dari data 5 tahun terakhir terlihat besarnya realisasi, tunggakan dan denda mengalami fluktuasi. Masih adanya tunggakan dan denda dari wajib pajak Kendaraan Bermotor di Kabupaten Gianyar menunjukkan masih kurangnya kepatuhan wajib pajak kendaraan bermotor di Kabupaten Gianyar. Kepatuhan wajib pajak harus menjadi perhatian utama bagi otoritas dalam prinsip administrasi pajak yang baik dan untuk menumbuhkan semangat pajak yang lebih banyak( Erzo \& Monica, 2014). Hal ini berkaitan dengan psikologi sosial barubaru ini berfokus pada mengubah norma sosial untuk memengaruhi perilaku, dimana kepatuhan dalam membayar pajak diharapkan bisa menjadi patokan dalam perilaku wajib pajak (Bobek et al, 2013).

Kepatuhan pajak didefinisikan sebagai pelaporan pendapatan yang akurat (Jugurnath, 2018). Kepatuhan pajak juga termasuk dalam klaim biaya sesuai 
dengan undang-undang pajak yang ditetapkarn (Sapiei et al , 2014). Perilaku kepatuhan pajak selalu menjadi masalah yang menjadi perhatian para pembuat kebijakan pajak, karena ketidakpatuhan terhadap persyaratan pelaporan memengaruhi pengumpulan pendapatan dan kemampuan pemerintah untuk mencapai tujuan fiskal dan sosialnya. Rochmat Soemitro menyatakan bahwa kepatuhan dalam teorinya digolongkan menjadi 2 teori lainnya. Teori tersebut adalah teori konsensus dan teori paksaan (Septiana\&Sukartha, 2015). Teori konsensus memiliki sistem hukum yang dijunjung oleh masyarakat sebagai suatu landasan ketaatan bermasyarakat. Teori konsensus dikaitkan dengan perpajakan menciptakan penerimaan oleh wajib pajak. Penerimaan ini adalah tentang sistem perpajakan yang berjalan.selain teroti konsesus, juga terdapat teori paksaan. Kekeuasaan yang bersifat legal mengingat kita hidup dinegara hukum membuat masyarakat dipaksakan untuk mematuhinya. Setiap perarturan yang ada pastilah diterapkan sanksi yang mengatur, termasuk pajak itu sendiri. pajak memilik sanksi berupa sanksi pidana maupun administrasi.

Fluktuasi pembayaran Pajak Kendaraan Bermotor tersebut terjadi akibat kurang konsistennya ketaatan para wajib pajak dalam menjalankan kewajibannya. Hal ini merupakan bentuk dari kesadaran wajib pajak mentaati kewajiban pajaknya. Kesadaran wajib pajak membuat wajib pajak berusaha untuk mematuhi karena mereka percaya itu hal yang benar untuk dilakukan, bukan karena takut akan hukuman jika mereka tidak mematuhi (Hauptman et al, 2014). Hal Yang paling penting, mereka tidak hanya termotivasi oleh kepentingan diri sendiri dan apa yang paling menguntungkan bagi mereka tetapi dengan motif tambahan, 
termasuk redistribusi, keadilan, timbal balik, kebiasaan sosial, norma dan moralitas adalah untuk mendorong komitmen sukarela atau bersedia untuk berperilaku yang patuh daripada untuk memaksa warga untuk mematuhi ancaman dan/ atau insentif (Korez-vide et al, 2015)). Regulasi yang responsif dengan adanya pembayaran pajak dengan official assesment system adalah tentang memenangkan hati dan pikiran pembayar pajak sehingga dapat menimbulkan budaya komitmen terhadap kesadaran pajak agar orang-orang akan sadar mengatur diri mereka sendiri (Williams, 2013). Kesungguhan maupun keinginan dari masing-masing diri wajib pajak, merupakan bentuk dari kesadaran wajib pajak. Hal ini menunjukan pula pemahaman pada fungsi pajak yang berlaku begitu pula sunguh-sungguhnya pembayaran pajak oleh wajib pajak. Tingkat kesadaran dari masing-masinh wajib pajak yang tinggi membuat semakin baik pelaksanaan maupun pemahaman untuk mematuhi kewajiban perpajakannya (Sugi \& Lely, 2017). Menurut penelitian dari (Adinata \& Supadmi, 2016) dan penelitian (Juniati \& Ery 2017)menyatakan yaitu kesadaran wajib pajak berpengaruh pada patuhnya pembayaran Pajak.

Selain adanya kesadaran diri dari wajib pajak, tanggung jawab dan kualitas pelayanan dari pihak penagih pajak juga menjadi alasan yang membuat wajib Pajak Kendaraan Bermotor mematuhi untuk membayarkan pajaknya. Gap theory merupakan teori yang menyebutkan bahwa penegertian dari kualitas pelayanan, suatu hal dibandingkan dari keinginan yang diharapkan para pelanggan dengan keadaan yang mereka nilai sendiri dari kinerja sesungguhnya suatu penyedia layanan. Pelayanan yang sesuai dengan apa yang diharapkan 
adalah bentuk kualitas pelayanan yang baik. Hal ini memiliki perbandingan yang lurus pada kemauan wajib pajak untuk melakukan kewajibannya, yaitu membayar pajaknya (Septiana \& Sukartha, 2015). Petugas dari pajak dengan pelayanan baik akan menigkatkan pendapat wajib pajak terhadap kualitas yang baik dalam pelayanan pajak. Hal ini bisa dalam bentuk kenyamanan saat wajib pajak melakukan pembayaran pajak. Saat wajib pajak nyaman maka meresaka akan semangat mematuhi kewajibanya(Rudolof dkk, 2017). Perlakuan yang baik, dan kepercayaan yang jelas dari otoritas pajak, serta kesempatan untuk menyatakan pendapat seseorang dapat meningkatkan motivasi intrinsik untuk membayar pajak. Sifat dari pengambilan keputusan dan kualitas hubungan antara otoritas pajak dan pembayar pajak seharusnya secara signifikan memengaruhi moral pajak, dan, pada akhirnya, kepatuhan pajak (Dzka, 2014). Menurut penelitian dari Adinata \& Supadmi (2016), penelitian Juniati \& Ery (2017), Putra (2015) dan Sentanu \& Setiawan (2016) menuliskan kualitas pelayanan pajak memiliki pengaruh pada kepatuhan pembayaran Pajak. Penelitian dari (Rudolof dkk, 2017) menyatakan perbedaan hasil, yaitu kualitas pelayanan pajak tidak memiliki pengaruh pada kepatuhan membayar pajak.

Sering terjadinya tilang yang merupakan bentuk pemeriksaan pajak juga sebagai salah satu faktor yang menyebabkan kepatuhan dari pembayaran Pajak Kendaraan Bermotor. Hal ini merupakan bentuk untuk meyeseuikan kepatuhan kewajiban tentang pajak yang dilaporkan oleh wajib Pajak Kendaraan Bermotor. Inspeksi dan pemeriksaan pajak biasanya merupakan perhatian yang jauh lebih penting di negara berkembang dan transisi, yang termasuk juga Indonesia 
(Coolidge, 2012). Frekuensi dan kecermatan pemeriksaan mampu memicu pembayar pajak semakin berhati-hati melaporkan pendapat mereka secara keseluruhan kemudian menyelesaikan pengembalian dan mengklaim potongan yang benar dalam menyelesaikan kewajiban pajak para wajib pajak(City et al, 2014). Menurut penelitian dari Tia \& Jati (2016)menuliskan yaitu pemeriksaan pajak memiliki pengaruh pada kepatuhan wajib pajak.

Kesadaran dari dari wajib pajak membuat wajib pajak berusaha untuk mematuhi karena mereka percaya itu hal yang benar untuk dilakukan, bukan karena takut akan hukuman jika mereka tidak mematuhi ( Hauptman et al, 2014). Hal yang paling penting, mereka tidak hanya termotivasi oleh kepentingan diri sendiri dan apa yang paling menguntungkan bagi mereka tetapi dengan motif tambahan, termasuk redistribusi, keadilan, timbal balik, kebiasaan sosial, norma dan moralitas adalah untuk mendorong komitmen sukarela atau bersedia untuk berperilaku yang patuh daripada untuk memaksa warga untuk mematuhi ancaman dan/atau insentif (Korez-vide, 2015). Teori kepatuhan dalam segi teori konsensus yang mana masyarakat taat dikarenakan menerima adanya hukum yang mengatur dimasyarakat adalah bentuk dari kesadaran diri masyarakat. Regulasi yang responsif/tentang memenangkan hati dan pikiran pembayar pajak sehingga dapat menimbulkan budaya komitmen terhadap keasadaran pajak agar orang-orang akan sadar mengatur diri (Williams, 2013).

Menurut penelitian dari Adinata \& Supadmi (2016) dan penelitian Juniati \& Ery (2017) menuliskan yaitu kesadaran wajib pajak memiliki pengaruh pada kepatuhan pembayaran Pajak Kendaraan Bermotor. Hal yang sama juga 
dinyatakan oleh penelitian ( Nirajenani \& Lely, 2018). Hasil penelitian terdahulu yang telah diuraikan menyimpulkan hipotesis penelitiaan sebagai berikut ini.

$\mathrm{H}_{1}$ : Kesadaran wajib pajak berpengaruh positif pada kepatuhan wajib Pajak Kendaraan Bermotor di Kabupaten Gianyar.

Baiknya Kualitas pelayanan tentu akan membuat khalayak wajib pajak semangat dalam memenuhi kewajibannya menaati kewajibannya(Septiana \& Sukartha, 2015). Fiskus yang sangat baik dalam melakukan tugasnya melayani wajib pajak, menaikan persepsi wajib pajak terhadap pelayanan yang baik pula. Hal ini akan menguindang kenyaman hati para wajib pajak untuk melakukan kewajibannya secara rutin. Hal tersebut adalah bentuk kepatuhan (Rudolof dkk, 2017).

Perlakuan yang baik, dan kepercayaan yang jelas dari otoritas pajak, serta kesempatan untuk menyatakan pendapat seseorang dapat meningkatkan motivasi intrinsik untuk membayar pajak. Sifat dari pengambilan keputusan dan kualitas hubungan antara otoritas pajak dan pembayar pajak seharusnya secara signifikan memengaruhi kepatuhan pajak(Dzka, 2014). Sisi psikologi dari para wajib pajak mampu menunjukan tingkat kepatuhan dalam perpajakan. Melalui Theory of Planned Behavior (TPB) tercermin riset didalam ranah psikologi yang menjabarkan beberapa alasan yang memengaruhi sikap kepatuhan pajak. TPB menyatakan sikap pribadi yang enggan berlaku mematuhi pada undang-undang pajak yang berlaku, dipengaruhi oleh niat. Niat dalam suatu perilaku dipengaruhi oleh 3 alasan yaitu behavioral belief (suatu perasaaan yang yakin dari hasil suatu prilaku dan evalusai berakhir dengan terbentuk variabel suatu sikap), normative belief (suatu perasaan yang yakin tentang harapan normatif dimana berakhir 
dengan menjadi variabel pada norma yang subjektif), control belief (keyakinan tentang faktor pendukung dan penghambat prilaku yang akan menghasilkan variabel kontrol perilaku yang dipersepsikan). Kesadaran wajib pajak, kualitas pelayanan pajak dan pemeriksaan pajak mampu dijadikan suatu alasan untuk ditentukan sikap kepatuhan pada perpajakan. Adanya motivasi dari kesadaran diri diikuti dengan adanya kualitas pelayanan pajak yang baik serta seringnya terjadi pemeriksaan pajak maka akan membuat para wajib pajak enggan untuk melanggar peraturan perpajakan. Hal ini adalah bentuk niat dari wajib pajak untuk melakukan kewajibannya sebagai wajib pajak dan merealisasikan dengan membayark kewajibannya tesebut dengan tepat waktu (Nirajenani \& Lely, 2018). Teori prilaku berencana dimana adanya kualitas pelayanan yang sangat baik tentu menaikan niat untuk menaati dalam hal membayar kewajiban perpajakan Menurut tulisan dari Adinata \& Supadmi (2016), penelitian Juniati \& Ery (2017), (Putra, 2015) dan (Sentanu \& Setiawan, 2016) menyatakan dimana tewrdapat pengaruh kualitas pelayanan pajak dalam kepatuhan pembayaran Pajak Kendaraan Bermotor. Hal yang sama juga dinyatakan oleh penelitian ( Nirajenani \& Lely, 2018). Berdasarkan hasil penelitian terdahulu tersebut maka hipotesis penelitiaan adalah berikut.

$\mathrm{H}_{2}$ : Kualitas pelayanan pajak berpengaruh positif pada kepatuhan wajib Pajak Kendaraan Bermotor di Kabupaten Gianyar.

Pemeriksaan yang sering terjadi dijalan menjadi salah satu faktor yang menyebabkan kepatuhan dari pembayaran Pajak Kendaraan Bermotor di Gianyar. Hal ini merupakan bentuk untuk menyesuaikan kebenaran tentang pajak yang dilaporkan oleh wajib Pajak Kendaraan Bermotor. Inspeksi dan pemeriksaan 
Ni Putu Krismayani dan Ni Ketut Lely Aryani Merkusiwati. Pengaruh ...

pajak biasanya merupakan perhatian yang jauh lebih penting di negara berkembang dan transisi seperti Indonesia (Coolidge, 2012). . Frekuensi serta kecermatan pemeriksaan mampu memicu pembayar kewajiban pajak semakin berhati-hati untuk menghitung pendapat mereka secara keseluruhan kemudian menyelesaikan pengembalian dan mengklaim potongan yang benar dalam menyelesaikan kewajiban pajak para wajib pajak (City et al, 2014). Teori kepatuhan dalam segi teori paksaan yang mana masyarakat taat dikarenakan hukum yang mengatur dimasyarakat bila tidak dipatuhi akan menimbulkan masalah yang diawali dari adanya pemeriksaan. Menurut penelitian dari (Tia \& Jati, 2016) menuliskan pemeriksaan pajak memiliki pengaruh pada kepatuhan wajib pajak. Penelitian terdahulu yang telah diuraikan menyimpulkan hipotesis penelitiaan sebagai berikut ini..

$\mathrm{H}_{3}$ : Pemeriksaan pajak berpengaruh positif terhadap kepatuhan wajib Pajak Kendaraan Bermotor di Kabupaten Gianyar.

\section{METODE PENELITIAN}

Suatu penelitian yang baik diperlukan perencanaan terlebih dahulunya. Perencanaan yang kemudian pelaksanaannya di cakup dalam desain penelitian. Pendekatan kuantitatif digunakan dalam penelitian kali ini, yang mana merupakan bentuk metode dalam meneliti populasi atau sampel dengan harapan mampu menguji penetapan hipotesis sebelumnya (Sugiyono, 2017: 13). Pendekatan penelitian asosiatif juga bisa menggambarkan penelitian ini. Hal ini terkait permasalahan yang diteliti. Penelitian asosiatif memiliki tujuan dengan mencari tahu apa hubungan antara variabel yang berjumlah 2 maupun lebih dari dua. 
Kabupaten Gianyar dipilih menjadi tempat penelitian ini. Adapun alasan melakukan penelitian di Kabupaten Gianyar, dikarenakan masihnya denda dan tunggakan berjumlah besar oleh masyarakat yang memiliki kewajiban membayar pajak bermotor di Gianyar menurut data yang dinyatakan dari Kantor UPT SAMSAT Gianyar.

Kepatuhan wajib pajak menjadi objek penelitian ini dalam melakaukan kewajibannya dalam membayar pajak bermotor di Gianyar dengan hipotesis dipengaruhi oleh kesadaran wajib pajak, kualitas pelayanan pajak beserta pajak dalam pemeriksaan.

Kepatuhan wajibpajak adalah variabel terikat untuk penelitian ini., Penelitian kali ini menggunakan pengukuran kepatuhan wajib pajak menurut (Nirajenani \& Lely, 2018) diukur dengan menggunakan indikator berikut ini 1)seluruh wajib pajak menaati atuan pada pajak kendaraan bermotor, 2) nominal yang terdapat pada Surat Tanda Nomor Kendaraan (STNK) merupakan nominal pembayaran oleh wajib pajak, 3) ketepatan waktu pembayaran oleh wajib pajak.

Kesadaran wajib pajak, kualitas pelayanan pajak dan pemeriksaan pajak yaitu 3 variabel bebas dalam proses penelitian kali ini. (Septiana \& Sukartha, 2015)mengatakan bahwa pemahaman, pelaksanaan dan mengetahui peraturan perpajakan adalah suatu kondisi saat seseorang memiliki kesadaran diri terhadap perpajakan. Hal ini juga harus dilakukan dengan sukarela dan benar. Penelitian kali ini menggunakan skala likert dimodifikasi 4 poin dan untuk mengukurnya digunakan 3 indikator yaitu mengetahui ketentuan perpajakan, pernyataan tentang pengetahuan peraturan yang di wadahkan pada undang-undang ketentuan 
Ni Putu Krismayani dan Ni Ketut Lely Aryani Merkusiwati. Pengaruh ...

perpajaknnya serta pengetahuan bagaimana pajak memiliki fungsi terhadap pengeluaran oleh negara, mengerti dan memaknai ketentuan suatu perpajakan, menjalankan peraturan perpajakan secara sukarela dan benar serta pernyataan mengenai pelaporan pajak dengan benar dan pelaporan pajak dengan sukarela.

Kualitas pelayanan merupakan suatu kegiatan atau suatu tindakan yang dilakukan suatu petugas pajak terhadap pihak terutang pajaknya, dengan dasarnya yang tidak berwujud dan tanpa membuat apapun menjadi kepemilikan. Penelitian ini untuk mengukur variabel kualitas pelayanan adalah dengan 5 indikator yang diambil dari penelitian (Adinata\&Supadmi, 2016) yaitu Kondisi fisik, keandalan, jaminan, daya tangggap, empati

Pemeriksaan merupakan suatu rangkaian penghimpunan yang kemudian datanya, keterangan, dan/atau buktinya diolah yang dilaksanakan dengan profesional dan objektif berlandaskan suatu patokan pemeriksaan. Hal ini bertujuan menguji patuh atau tidaknya dalam memenuhi kewajiban pada pajaknya maupun bertujuan untuk sesantiasa menaati hal yang telah ditentukan dari undang-undang pada peraturan perpajakan yang saat ini berjalan. Penelitian kali ini untuk mengukur variabel pemeriksaan pajak digunakan 4 item yang dikembangkan oleh (Mika, 2015). Indikator-indikator tersebut adalah sebagai berikut 1) tahapan pemeriksaan suatu Pajak Kendaraan Bermotor pertama surat perintah pemeriksaan dari instansi terkait ada oleh pemeriksa, 2) tanda pengenal resmi digunakan oleh aparat pemeriksa pajak dalam melakukan pemeriksaan beserta surat perintah tugas pemeriksaan yang legal, 3) objektif terhadap apa yang 
diperiksa petugas saat bertugas, 4) jumlah yang kita bayar sesuai dengan apa yang diperekisa petugas pajak.

Wajib Pajak Kendaraan Bermotor secara keseluruhan yang aktif dan terdaftar pada kantor UPT SAMSAT (Sistem Manunggal Satu Atap) Kabupaten Gianyar tahun 2017 adalah sebanyak 195.849 wajib Pajak Kendaraan Bermotor. Jumlah tersebut adalah besarnya populasi. Metode accidental sampling digunakan pada penelitian kali ini. Metode ini memiliki pengertian pada saat dilokasi penelitian, peneliti bisa menggunakan siapa saja yang sesuai dengan kecocokan data yang menjadi sumber (Sugiyono, 2017:144). Pemilik kendaraan plat hitam adalah kriteria sampel. Rumus Slovin digunakan untuk menghitung besaran sampel yang akan diteliti dan hasil perhitungannya adalah 100 wajib pajak ( Husein, 2008:78).

Program SPSS (Statistical Product and Service Solution) versi 16.0 digunakan sebagai program untuk analisis linier berganda yang merupakan teknik analisi data dalam pemecahan masalah penelitian kali ini. Uji asumsi klasik adalah uji yang didahulukan sebelum mengregresikan penelitian ini. Tahap analisis yang dilakukan adalah uji normalitas, multikolinearitas, uji heteroskedastisitas. Selanjutnbya dilanjutkan dengan uji statistik deskriftif. Analisis sebuah regresi linear yang berganda tergunakan dalam pengujian untuk hipotesis. Hal ini dilakukan setelah uji asumsi klasik. Analisis bertujuan melihat bagaimana suatu kepatuhan pada pembayaran pajak bermotor dipengaruhi oleh kesadaran pada diri wajib pajaknya, kualitas pada pelayanan perpajakannya dan cermat tidaknya 
pemeriksaan oleh petugas. persamaan analisis regresi linier berganda ini adalah bentuk model dari penelitian kali ini..

$: Y=\beta_{0+} \beta_{1} X_{1+} \beta_{2} X_{2}+\beta_{3} X_{3}+e$

Keterangan :

$\mathrm{Y}=$ kepatuhan wajib pajak dalam membayar Pajak Kendaraa Bermotor

B $\quad=$ konstanta

$\beta_{1}, \beta_{2,} \beta_{3}=$ koefisien regresi

$\mathrm{e} \quad=$ variabel pengganggu

$\mathrm{X}_{1} \quad=$ Kesadaran wajib pajak

$\mathrm{X}_{2} \quad=$ kualitas pelayanan pajak

$\mathrm{X}_{3} \quad=$ pemeriksaan pajak

\section{HASIL DAN PEMBAHASAN}

Kabupaten Gianyar adalah kabupaten yang terdapat di Provinsi Bali. Luas dari Kabupaten Gianyar adalah $368 \mathrm{~km}^{2}$ atau 36.800 Ha. Potensi-potensi sumber daya yang terdapat di Kabupaten Gianyar adalah pariwisata, pertanian, industri pengolahan, bangunan, tambang \& galian, perdagangan, hotel \& restoran, jasa perusahaan, komunikasi dan angkutan, persewaan keuangan, dan, jasa-jasa.

Karakteristik responde menyatakan yaitu sebagian banyak responden adalah laki-laki, yaitu 74 orang atau 74 persen dan sisasanya yaitu 26 orang atau 26 persen adalah responden perempuan. Dari karakteristik umur, sebagian besar responden berumur diatas 30 tahun dengan jumlah sebanyak 76 persen(76 orang). Responden dengan jumlah terbawah didominasi usia 26-30 tahun, yaitu 11 jiwa atau 11 persen, sedangkan sisanya adalah kelompok umur 20-25 tahun yaitu 13 orang atau 13 persen. Karakteristik tingkat pendidikan responden tertinggi adalah tingkat pendidikan SMA yaitu sebanyak 56 orang atau 56 persen. Responden 
dengan jumlah tingkat pendidikan terendah adalah S2 yaitu sebanyak 2 orang atau 2 persen.

Validnya instrumen merupakan alat untuk mengukur yang tergunakan dalam mendapatkan suatu data yang valid. Valid adalah keadaan suatu alat(instrumen) yang bisa tergunakan dengan baik mengukur yang akan diukur (Sugiyono, 2017:172). Valid atau tidaknya suatu pernyataan bila koefisien pada korelasi dalam item pada penelitian bernilai positif, lebih besar dari kolerasi besarnya $r_{\text {tabel }}$ dalam taraf signifikasi $5 \% \mathrm{~N}=100$. Hasil perhitungan komputer dibantu program SPSS versi 16.0. Didapatkan korelasi dari total nilai masingmasing item dengan total nilai semua item. Koefisien hubungan product moment dari Karl Pearso digunakan dalam model uji validitas. Penghitungan korelasi antara masing-masing pernyataan dengan total pada jumlah dilakukan secara statistik yang dibandingkan dengan besaran angka kritis pada tabel korelasi. Pernyataan valid jika koefisien korelasinya lebih kecil dari nilai kritis (Sig> alpha(0,195)) begitu juga sebaliknya. Dari hasil pengujian $r$ product moment semua data valid. Jal ini mencangkup semua indikator pada setiap variabel bebas dan variabel terikat.

Uji reabilitas adalah untuk melihat bagaimana ketepatan pengisian kuisioner dalam periode yang berubah-ubah satu dan lainnya. Reliabelnya suatu alat pengukuran yang dipakai bilamana koefisien dari cronbach alpha $>0,060$. Reabilitas yang mendekati 1 pada besaran alphanya merupakan bentuk reliabilitas yang baik. Hal ini membuat yang membuat butir-butir pertanyaan kusioner penelitian dinyatakan andal. Kriteria reabilitas $\alpha$ lebih besar dari 0,6 dan begitu 
Ni Putu Krismayani dan Ni Ketut Lely Aryani Merkusiwati. Pengaruh ...

juga sebaliknya . Hasil penelitian menyatakan realiabel pada semua variabel. Hal ini terlihat koefisien yang lebih besar dari 0,6.

Statistik deskpriptif penelitian tersajikan demi informasi tentang variabel dalam karakteristiknya pada penelitian dengan menjabarkan nilai rata-rata, maksimun, minimun beserta simpangan baku. Besaran minimum dari kesadaran wajib $\operatorname{pajak}\left(\mathrm{X}_{1}\right)$ adalah 10 sedangkan besaran maksimummnya sebesar 20. Rata-rata besaran kesadaran dari wajib pajak adalah sebesar 15,93 berikut simpangan bakunya 2,65244 .

Variabel kualitas pelayanan pajak $\left(\mathrm{X}_{2}\right)$ memiliki nilai minimum 11 sedangkan nilai maksimummnya sebesar 20. Rata-rata dari nilai kualitas pelayanan pajak adalah sebesar 15,99 dengan standar deviasi 2,58392

Variabel pemeriksaan $\operatorname{pajak}\left(\mathrm{X}_{3}\right)$ memiliki nilai minimum 8 sedangkan nilai maksimummnya sebesar 16. Rata-rata dari nilai pemeriksaan pajak adalah sebesar 12,67 dengan standar deviasi 2.18838.

Variabel kepatuhan wajib(Y) pajak memiliki besaran minimum 3 sedangkan besaran maksimummnya yaitu 12 . Rata-rata dari nilai pemeriksaan pajak adalah sebesar 8,22 dengan standar deviasi 2.58816.

Distribusi normal dalam hasil penelitian sangat diperlukan, maka dari itu perlu adanya pengujian normalitas. Normalnya model data menunjukan model regresi yang baik. Normal tidaknya nilai pada hasil uji terlihat bila lebih kecil dari nilai hitungnya. Level of significant yang dipakai memiliki nilai yang lebih kecil dari sig(2tailed) akan membuat Ho diterima. Sehingga halisnya adalah residual yang teranalisis normal pada distribusinya .Kolmogorov-Smirnov test untuk uji 
normalitas. Hasil nilai Sig (2-tailed) pada uji normalitas Kolmogorov-Smirnov test menunjukkan bahwa $)(0,150)>$ dari level ofsignificant $(0,05)$, jadi simpulannya adalah kedaran dari para wajib pajak, kualitas pelayanan pajak beserta pemeriksaan pajak pada kepatuhan oleh wajib pajak kendaraan bermotor berdistribusi normal.

Hubungan yang linier diantara variabel bebas yang dipakai dalam penelitian membuat hasil pene;itian menjadi tidak baik, maka dari itu diperlukan Uji multikolinearitas.ini. Nilai VIF (Varians Inflation Factor) kurang dari empat menjadi pedoman variabel-variabel bebas satu sama lain tidak mengandung hubungan multikolinearitas. Gejala multikolinearitas tidak terlihat. variabel yang independen $\left(\mathrm{X}_{1}, \mathrm{X}_{2}\right.$ dan $\left.\mathrm{X}_{3}\right)$ masing-masing memperoleh nilai lebih rendah 4 pada persamaan dalam bentuk regresi . Dengan demikian model yang diajukan terbebas multikolinearitas.

Pengujian heteroskedatisitas bertujuan melihat dalam model regresi apakah terjadi perbedaan satu varian dan lainnya pada residual yang dilihat pada pengamatan yang berbeda-beda. Nilai probabilitas signifikansi menunjukan satu persatu variabel bebas memiliki nilai lebih banyak daripada 0,05, sehingga menunjukan penelitian terbebas dari hetroskedatisitas dalam model regresinya.

Analisis regresi linier berganda digunankan untuk melihat bagaimana pengaruh kesadaran dari wajib pajak, kualitas pelyanan pajak beserta pemeriksaan pajak dalam kepatuhan membayar pajak kendaraan bermotor di Kabupaten Gianyar. 
Tabel 2.

Analisis Regresi Linier Berganda

\begin{tabular}{|c|c|c|c|c|c|c|}
\hline \multirow[b]{2}{*}{ Model } & & \multicolumn{2}{|c|}{$\begin{array}{c}\text { Unstandardized } \\
\text { Coefficients }\end{array}$} & \multirow{2}{*}{$\begin{array}{l}\text { Standardize } \\
\text { d } \\
\text { Coefficients } \\
\text { Beta } \\
\end{array}$} & \multirow[b]{2}{*}{$\mathrm{T}$} & \multirow[b]{2}{*}{ Sig. } \\
\hline & & B & $\begin{array}{l}\text { Std. } \\
\text { Error }\end{array}$ & & & \\
\hline \multirow[t]{4}{*}{1} & (Constant) & - & .406 & & $\begin{array}{l}- \\
18.3 \\
20\end{array}$ & .000 \\
\hline & $\begin{array}{l}\text { Kesadaran } \\
\text { Wajib Pajak } \\
\left(\mathrm{X}_{1}\right)\end{array}$ & .555 & .063 & .569 & $\begin{array}{l}8.85 \\
4\end{array}$ & .000 \\
\hline & $\begin{array}{l}\text { Kualitas } \\
\text { Pelayanan } \\
\text { Pajak }\left(X_{2}\right)\end{array}$ & .247 & .057 & .246 & $\begin{array}{l}4.29 \\
0\end{array}$ & .000 \\
\hline & $\begin{array}{l}\text { Pemeriksaan } \\
\text { Pajak }\left(X_{3}\right)\end{array}$ & .227 & .063 & .192 & $\begin{array}{l}3.62 \\
1\end{array}$ & .000 \\
\hline $\begin{array}{l}\mathrm{R} \\
\mathrm{R} \\
\mathrm{Fl} \\
\mathrm{Si}\end{array}$ & 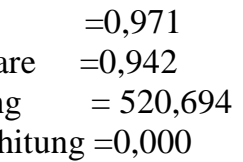 & & & & & \\
\hline
\end{tabular}

Sumber : Data diolah 2018

Berikut ini merupakan persamaan garis linier berganda

$$
\ddot{Y}=-7,434+0,555 X 1+0,247 X 2-0,227 X 3
$$

Kesadaran wajib pajak memiliki koefisien dengan nilai $\left(X_{1}\right)=0,555$ memiliki pengertian kesadaran wajib pajak $\left(\mathrm{X}_{1}\right)$ jika dinaikan satu dalam satuan yang mana tidak ada perubahan pada variabel lainnya membuat terjadinya peningkatan patuhnya orang- orang yang memiliki kewajiban membayar pajak sebesar dalam satuan 0,555 . Hal tersebut menunjukan kenaikan kesadaran diri bagi orang-orang yang memiliki kewajiban pada perpajakan mampu menaikan kepatuhannya pula. Nilai regresi kualitas pelayan pajak $\left(\mathrm{X}_{2}\right)$ sebesar 0,247 memiliki pengertian kualitas pelayan pajak $\left(\mathrm{X}_{2}\right)$ jika dinaikan satu dalam satuan dari variabel lainnya tidak berubah membuat sikap patuh dari orang- orang yang memiliki kewajiban pada pajak pasti naik sebesar 0,247 dalam. Hal tersebut 
menyatakan dimana setiap naiknya kualitas pada pelayanan pajak mampu menaikan sikap patuh para orang-orang yang memeiliki kewajiban terhadap perpajakan. Pemeriksaan pajak $\left(\mathrm{X}_{3}\right)$ memiliki koefisien dengan nilai $\left(\mathrm{X}_{3}\right)=0,227$ memiliki pengertian pemeriksaan pajak $\left(X_{3}\right)$ jika dinaikan satu dalam satuan dari variabel lainnya tidak berubah membuat sikap patuh dari orang- orang yang memiliki kewajiban pada pajak pasti naik sebesar 0.227 dalam satuan. Hal ini menunjukan kenaikan pemeriksaan pajak mampu menaikan kepatuhan wajib pajak.

Kemampuan dari variabel bebas menerangkan bagaimana hubungannya deengan variabel terikat ditunjukan dengan hasil uji koefisien determinasi. Hal ini terlihat dari $R^{2}$ pada Tabel 2., yaitu besarnya $R^{2}$ memiliki nilai 0,942 , mengindikasikan 94\% sikap patuh dari wajib pajak di pengaruhi oleh sadarnya setiap oarang-orang yang memiliki kewajiban perpajakan, kualitas pelayanan dari para petugas pajak dan kecermatan para petugas melakukan pemeriksaan pada pajak. $6 \%$ lainnya terpengaruh hal lain yang tidak dijabarkan pada penelitian ini.

Layak atau tidaknya model regresi ditunjukan oleh hasil uji F. Selain itu juga menguji masing-masing variabel terhadap variabel terikatnya. Tabel 2 . menunjukan besaran signifikansi dibawah 0,05 yang telah ditentukan, yaitu 0,00. Hal ini mengindikasikan secara simultan patuhanya para pemiliki kewajiban dalam perpajaknya di pengaruhi sadarnya para pemiki kewajiban dalam paja, kualitas pelayanan oleh petugas pajak beserta cermatanya para petugas pemeriksaan. 
Variabel bebas masing-masing diduga memiliki pengaruh terhadap variabel terikat. Penagruh tersebut akan dilihat pada uji t. Hasil uji t maupun besaran signifikansi dalam variabel kesadaran wajib pajak $\left(\mathrm{X}_{1}\right)$ memiliki besar 0,00 tentu saja lebih sedikit dari 0,05 maka Ho di tolak. Hal tersebut mengindikasikan positifnya pengruh dari sadarnya diri para wajib pajak pada patuhnya para wajib pajak. Hasil dai uji t maupun nilai signifikansi pada variabel kualitas pelayanan pajak $\left(\mathrm{X}_{2}\right)$ menghasilkan nilai sig 0,00 yang tentu saja lebih sedikit dari 0,05 maka Ho ditolak. Hal tersebut mengindikasikan pengaruh yang positif dari kualitas pada pelayanan pajak terhadap kepatuhan dari oarang-orang yang memiliki kewajiban untuk membayar pajak. Berdasarkan hasil uji t dan nilai signifikansi pada variabel Pemeriksaaan pajak $\left(\mathrm{X}_{3}\right)$ menghasilkan nilai sig 0,00 yang tentu saja lebih sedikit dari 0,05 maka Ho ditolak. Hal tersebut mengindikasikan terdapat pengaruh yang positif oleh pemeriksaan pajak untuk sikap patuh dari para wajib pajak.

Signifikansi dengan nilai 0,00 , dimana dibawah dari batas yang telah ditentukan pada hipotesis yaitu 0,05 menunjukan masyarakat akan bersikap patuha untuk membayar kewajibannya pada perpajakan bila dipicu oleh kesadaran dalam diri wajib pajak tersebut begitu juga dengan sebaliknya. Hubungan ini adalah hubungan yang positif. Hasil dari kuisioner dengan modus 3 dan 4 menunjukan bahwa tingginya kesadaran wajib pajak . Nilai minimum 1 yang ada pada pernyataan tentang kesukarelaan dalam membayar pajak, menunjukan bahwa masih terdapat masyarakat yang sedikit kurang sadar untuk membayar pajak. Hasil ini membuktikan teori kepatuhan dalam segi teori konsensus yang mana masyarakat taat dikarenakan menerima adanya hukum yang mengatur 
dimasyarakat. Penelitian dengan hasil yang searah mampu dibuktikan dengan hasil penelitian kali ini yaitu penelitian dari Adinata \& Supadmi (2016) menyatakan bahwa kesadaran wajib pajak berpengaruh pada kepatuhan wajib pajak hotel di Kabuipaten Klungkung. Penelitian dari Nirajenani dan Lely (2018)menyatakan bahwa kesadaran wajib pajak yang meninggi akan membuat kepatuhan wajib pajak yang meninggi pula.

Baiknya kualitas dari para petugas perpajakan juga mempengaruhi patuhnya wajib pajak dalam membayarkan kewajibannya dan begitu juga sebaliknya, saat para wajib pajak tidak merasa nyaman pada pelayanan pajak maupun terjadi perbedaan anatara harapan dan kenyataan pada kualitas pelayanan maka akan menyebabkan menurunnya keinginan untuk bersikap patuh pada pembayaran kewajibannya. Hubungan ini adalah hubungan yang positif, yang dilihat juga dari nilai signifikasi variabel ini dibawah 0,05 yaitu 0,00 . Hasil ini juga tercermin dari jawaban responden pada kuisioner yang ditunjukan dengan modus dari masing-masing butir pertanyaan sebesar 3 dan 4 yang menunjukan bahwa kualitas pelayan pajak yang baik dimata sebagian besar masyarakat. Nilai minimum 1 yang terdapat pada pernyataan kondisi gedung dan pemberian informasi dari petugas menunjukan bahwa masih ada beberapa persepsi masyarakat yang menunjukan sedikit kurang baiknya kualitas pelayanan pajak. Hasil ini membuktikan prilaku berencana dimana adanya kualitas pelayanan yang membuat nyaman maka akan menaikan niat untuk melakukan kepatuhan dalam hal membayar kewajiban perpajakan. Penelitian sebelumnya yang dilakukanoleh beberapa peneliti mampu dibuktikan lagi keempirisannya dengan adanya hasil 
penelitian ini, diantaranya oleh Juniati dan Ery (2017) yaitu kualitas pelayanan pajak berpengaruh positif signifikan pada kepatuhan wajib pajak orang pribadi di KPP Denpasar Timur. Hasil ini juga mendukung penelitian Sentanu \& Setiawan (2016) yang menghasilkan kualitas pelayanan pajak berpengaruh pada kepatuhan wajib pajak hotel di Kabupaten Badung.

Kecermatan, kesopanan dan rajin tidaknya terjadi pemeriksaan pajak akan memicu para wajib pajak untuk melakukan kewajiban perpajakannya. Sebaliknya bila masyarakat jarang disuguhi pemeriksaan pajak yang dibarengi dengan pengecekan status kendaraan akan membuat masyarakat merasa baik-baik saja bila belum melaksanakan kewajibannya, hal ini juga akan memicu tidak tertibnya pada hukum yang berlakuk tentang berkendara. Hasil ini juga didukung dengan modus dari jawaban responden yang ada pada rentang 3 dan 4 yang salah satunya merupakan nilai maksimum masing-masing pernyataan. Nilai minimum 1 dari masing- masing pernyataan menyatakan bahwa masih ada beberapa persepsi masyarakat yang menyatakan bahwa pemeriksaan pajak kendaraan bermotor masih kurang maksimal.Hasil ini membuktikan teori kepatuhan dalam segi teori paksaan yang mana masyarakat taat dikarenakan hukum yang mengatur dimasyarakat bila tidak dipatuhi akan menimbulkan masalah yang diawali dari adanya pemeriksaan. Hasil dari penelitiaan ini senada pada penelitian yang dilakukan oleh Tia dan Jati (2016) yaitu pemeriksaan pajak berpengaruh positif signifikan pada kepatuhan wajib pajak hotel di Dinas Pendapatan Kota Denpasar.

Implikasi hasil pada penelitian ini dapat ditunjukan untuk pengembngan teori akademis dan kebijakan. Implikasi teoretis pada penelitian ini menghasilkan 
simpulan rasa sadar akan kewajiban sebagai wajib pajak, kualitas dari para petugas pajak dan pemeriksaan pajak yang dilakukan berkala akan memicu sikap untuk selalu membayarkan kewajiban pajaknya secara baik dan tepat waktu. Hasil penelitian ini diharapkan menambah penegtahuan dan wawasan bagaimana theory of planned behavior dan teori kepatuhan bermanfaat dalam memebrikan bukti empiris menegnai pengaruh kesadaran wajib pajak, kualitas pelayanan pajak dan pemeriksaan pajak pada tingkat kepatuhan wajib pajak dalam membayar pajak kendaraan bermotor. Penelitian juga memiliki implikasi praktis dalam hal dapat memberikan kontribusi positif terutama bagi pihak yang bekepentingan seperti para wajib pajak dalam meningkatkan kesadaran diri dalam membayar pajak. Adanya kualitas pelayan yang baik dan pemeriksaan pajak yang sering maka akan meningkatkan sikap patuh membayar pajak dari para wajib pajak. Hasil penelitian juga baik digunakan sebagai bahan pertimbangan kebijakan apa yang bisa ditingkatkan dimasa dengan dan juga mampu mengevalusai kebijakan yang sudah berjalan saat ini. Dimasa akan data dalam membuat suatu kebijakan agar kepatuhan wajib pajak bermotor dapat meningkat. Akademisi yang akan datang diharapkan terbantu oleh hasil dari penelitian kali ini, yang mana mampu menjadi sumber maupun acuan penelitian.

\section{SIMPULAN}

Hasil analisis dan pembahasan yang sudah terjabarkan menghasilkan beberapa simpulan. Kesadaran wajib pajak berpengaruh signifikan pada kepatuhan wajib 
pajak. Kualitas pelayanan pajak berpengaruh signifikan pada kepatuhan wajib pajak. Pemeriksaan pajak berpengaruh signifikan pada kepatuhan wajib pajak.

Penelitian yang sudah dilakukan memiliki beberapa saran untuk kedepannya. Bagi pemerintah daerah Kabupaten Gianyar terutama instansi-instasi yang sudah diberikan wewenang untuk memungut Pajak Kendaraan Bermotor diharapkan lebih persuasif menghimbau masyarakat untuk lebih sadar dan peka terhadap undang-undang yang berlaku terutama dalam bidang perpajakan. Pajak yang merupakan sumber pendapatan utama daerah tentunya disalurkan kembali ke masyarakat walaupun tidak dalam bentuk langsung. Kondisi gedung, teknologi dan pelayanan pada Kantor UPT SAMSAT Gianyar juga perlu ditingkatkan untuk membuat wajib pajak lebih nyaman dalam membayar kewajibannya. Penyebaran informasi tentang adanya E-SAMSAT juga perlu diperluas agar lebih memudahkan masyarakat terutama tidak membuang waktu terlalu lama dalam menunggu giliran pembayaran. Para peneliti dimasa yang akan data disarankan untuk meneliti beberapa faktor yang mungkin mampu memengaruhi kepatuahn pajak seperti kewajiban pajak dengan moral, biaya dalam administrasi, tingkatan pengeluaran para wajib pajak.

\section{REFRENSI}

Adinata K, I. B. \&Supadmi, Ni Luh. (2016). Pengaruh Kesadaran, Kulaitas Pelayanan, Sanksi, dan Pemahaman Peraturan Perpajakan pada Kepatuhan Wajib Pajak Hotel. E-jurnal Akuntansi Universitas Udayana, 17(1), 565590. ISSN: 2302-8556.

Adi P. S., I Putu. (2014). Pengaruh Kualitas Pelayanan, Kewajiban Moral dan Sanksi Perpajakan pada Kepatuhan Wajib Pajak dalam Membayar Pajak Hotel. E-jurnal Akuntansi Universitas Udayana, 7(1), 207-222. ISSN: 2302- 
8556.

Akinboade, O. A.(2015). Correlates of Tax Compliance of Small and Medium Size Businesses in Cameroon, Journal of Gordon Institute of Business Science,SouthAfrica.13(4),389-

413.https://ideas.repec.org/a/mgt/youmgt/v13y2015i4p389-413.html

Arum S., Ni Made \& Sukartha, I Made. (2017). Pengaruh Pengetahuan, Pelayanan, Biaya Kepatuhan, dan Sanksi pada Kepatuhan Wajib Pajak dalam Membayar Pajak Hotel. E-jurnal Akuntansi Universitas Udayana, 20(1), 231-260. ISSN : 2302-8556.

Bobek, D. D., Hageman, A. M., \& Kelliher, C. F. (2013). Analyzing the Role of Social Norms in Tax Compliance Behavior, 451468.https://doi.org/10.1007/s10551-012-1390-7

City, M., Engida, T. G., \& Baisa, G. A. (2014). Factors Influencing t axpayers ' compliance with the tax system: An empirical study, 12(2), 433453.https://www.researchgate.net/publication/286354639_Factors_influencin g_Taxpayers'_Compliance_with_Tax_System_An_Empirical_Study_of_Me kelle_City_Ethiopia

Coolidge, J. (2012). Findings of tax compliance cost surveys in developing countries, 10(2),250-287.

https://www.researchgate.net/publication/289057368_Findings_of_tax_comp liance_cost_surveys_in_developing_countries

Cintya D., A.A.A \& Lely A. M., Ni Ketut.(2013) . Analisis Kepatuhan Wajib Pajak atas Pemenuhan Kewajiban Pajak Hotel dan Restoran di Kabupaten Badung Tahun 2011. E- Jurnal Akuntansi Universitas Udayana, 4(1); 110127. ISSN: 2302-8556.

Dzka, M. N. (2014). Relations between Procedural Fairness, Tax Morale, Institutional Trust and Tax Evasion, 5(1).https://www.researchgate.net/publication/297361514_Relations_betwee n_procedural_fairness_tax_morale_institutional_trust_and_tax_evasion

Ghozali, Imam. 20016. Aplikasi Analisis Multivariate dengan Program SPSS. Edisi keempat. Semarang: BP UNDIP.

Gunadi. 2005. Akuntansi Pajak. Jakarta : PT. Gramedia Widiasarana

Husein, Umar. 2008. Metode Penelitian Untuk Skripsi dan Tesis Bisnis Edisi Kedua. Jakarta: PT. Rajagrafindo Persada.

Hauptman, Lidjia, Horvat, Mirjana \& Korez V., Romana. (2014)Improving Tax 
Administration $\hat{a} €^{\mathrm{TM}}$ s Services as a Factor of Tax Compilance : The Case of Tax Audit. Lex Locals- Journal of Self-Governent, 12(3), 481-501. https://doi.org/10.4335/12.3.481-501(2014)

Jugurnath, B. (2018). Ct-Model: An Explanation Of Corporate Tax Payers ' Attitude, 52(3). https://muse.jhu.edu/article/677944/pdf

Juniati P., Kadek \& Ery S., Putu. (2017). Pengaruh Kesadaran, Pengetuahuan dan Pemahaman Perpajakana, Kualitas Pelayanan dan Sanksi Perpajakan terhadap Kepatuhan Wajib Pajak. E- Jurnal Akuntansi Universitas Udayana, $18(2)$; 1112-1140. ISSN 2303-8556.

Kaluge, D; Multifiah; Munawar. (2015). Taxes Performance Analysis as a Source of Local Revenue in the City of Pekanbaru, 3(2), 3545.https://www.scribd.com/document/359672944/jurnal-PAD.

Korez-vide, R.; Hauptman, Lidija; Gurada, Sevin (2015). Exploring Voluntary Tax Compliance Factors in Slovenia: Implications for Tax Administration and Policymakers, 13(3), 639-659. https://doi.org/10.4335/13.3.639$659(2015)$

Luttmer, E. F. P., \& Singhal, M. (2014). Tax Morale, 28(4), 149168.http://users.nber.org/ luttmer/taxmorale.pdf

Mardiasmo. 2016. Perpajakan. Edisi Revisi Tahun 2016. Yogyakarta: Penerbit Andi

Mika, Ni Luh. 2015. Analisa Faktor-Faktor yang Memengaruhi Kepatuhan Wajib Pajak Membayar Pajak Kendaraan Bermotor, Pajak Restoran, dan Pajak Hiburan di Kota Denpasar. Tesis pada Jurusan Akuntansi Fakultas Ekonomi dan Bisnis Universitas Udayana.

Mohdali, R., Benk, S., Budak, T., Mohdisa, K., \& Yussof, S. H. (2017). A crosscultural study of religiosity and tax compliance attitudes in Malaysia and Turkey, 15(3), 490-505.

Nirajenani, C.I.P. \& Lely A.M. Ni Kt. (2018). Faktor-faktor yang memengaruhi Kepatruhan Wajib Pajak dalam Membayar Pajak Kendaraan Bermotor. . EJurnal Akuntansi Universitas Udayana .24(1).; 339-369. ISSN: 2302-8556.

Peraturan Bupati Gianyar No. 141 Tahun 2015

Prastiwi, Dewi dan Dudy Satyawan, Made. 2014. Identifikasi Permasalahan Tunggakan Pajak Bumi dan bangunan (PBB) di Wilayah Kabupaten Madiun. Jurnal Ilmiah Akuntansi dan Bisnis. Vol. 9 No. 2. Juli: 74-83. 
Putra M., I G. N. (2015). Pengaruh Kualitas Pelayanan dan Sikap Wajib Pajak terhadap Kepatuhan Pelaporan Wajib Pajak Orang Pribadi di KPP Pratama Singaraja. Jurnal Jurusan Pendidikan Ekonomi, 5(1); 1:12.

Sri M. P., I. G. A. \& Lely A. M., Ni Ketut. (2018). Faktor-faktor yang memengaruhi Kepatuhan Wajib Pajak di Kabupaten Gianyar. E-journal Akunbtansi Universitar Udayana. 23(1): 461-488.

DOI: https://doi.org/10.24843/EJA.2018.v23.i01.p18

Wirya S., I Nyoman \& Ery S., Putu.(2016). Pengeruh Kualitas Pelayanan, Kewajiban Moral dan Sanksi Perpajakan pada Kepatuhan Wajib Pajak Hotel. E-jurnal Akuntansi Universitas Udayana. 16(1), 306-332. ISSN: 2302-8556.

Rudolof A. T., Jullie J. S., Sherly. P. (2017). Pengaruh Kesadaran Wajib Pajak, Kualitas Pelayanan Fiskus Dan Sanksi Pajak Terhadap Kepatuhan Wajib Pajak Orang Pribadi Di Kpp Pratama Bitung. Jurnal Riset Akuntansi Going Concern, 12(2), 296-303.

Saad N.(2014). Tax Knowledge, Tax Complexity and Tax Compliance: Taxpayers' View. Procedia- Social and Behavioral Sciences 2014; 109: 1069-

1075.https://www.sciencedirect.com/science/article/pii/S187704281305229 4

Sapiei, N. S., Kasipillai, J., \& Eze, U. C. (2014). Determinants of tax compliance behaviour of corporate taxpayers in Malaysia. 12(2), 383410.https://www.researchgate.net/publication/281733049_Determinants_of_t ax_compliance_behaviour_of_corporate_taxpayers_in_Malaysia

Sugiyono.2017. Metode Penelitian Bisnis.Bandung:Alfabeta

Sugi Astana \& Lely A. M., Ni Ketut (2017). Pengaruh Penerapan Sistem Administrasi Perpajakan Modern dan Kesadaran Wajib Pajak pada Kepatuhan Wajib Pajak.. E-Jurnal Akuntansi Universitas Udayana , 18(1), 818-846. ISSN: 2302-8556

Tia D. P., Putu \& Jati, I Ketut. (2016). Pengaruh Kondisi Keuangan Perusahaan, Pemeriksaan Pajak dan Sikap Wajib Pajak terhadap Kepatuhan Wajib Pajak Hotel. E-jurnal Akuntansi Universitas Udayana, 17(1), 663-689. ISSN : 2302-8556.

Septiana D., Putu \& Sukartha, I Made.(2015). Faktor-Faktor yang Mempengaruhi Kepatuhan Wajib Pajak dalam Membayar Pajak Hotel. E- Jurnal Akuntansi Universitas Udayana, 13(2); 599-614. ISSN : 2302-8556. 
Ni Putu Krismayani dan Ni Ketut Lely Aryani Merkusiwati. Pengaruh ...

Williams, C. C. (2013). Tackling Europe's Informal Economy: A Critical Evaluation of the Neo-liberal De-regulatory Perspective, 9(2), 261278.https://www.researchgate.net/publication/289408994_Tackling_Europe's _Informal_Economy_A_Critical_Evaluation_of_the_Neo-liberal_Deregulatory_Perspective

Young, A., Lei, L., Wong, B., \& Kwok, B. (2016). Individual tax compliance in China : a review, ,562-574. https://doi.org/10.1108/IJLMA-12-2015-0063 